\title{
Inheritance of $\beta$ Hemoglobin Gene Mutation: Potential Method of Newborn Screening of Sickle Cell Anemia in Bangladesh
}

\author{
Fariha Khan Laura ${ }^{1}$ (D), Md. Faruque Miah ${ }^{1^{*}}$ (D), Sanjana Fatema Chowdhury ${ }^{1^{* *}}$ (D), \\ Saeed Anwar ${ }^{1,2}$ (D), Riyan Al Islam Reshad ${ }^{1}$ (D), Mohammad Golam Rob Mahmud ${ }^{3}$ (D), \\ Chowdhury Muhammad Omar Faruque 4 (D)
}

${ }^{1}$ Department of Genetic Engineering and Biotechnology, School of Life Sciences, Shahjalal University of Science and Technology, Sylhet, Bangladesh

${ }^{2}$ Department of Medical Genetics, Faculty of Medicine and Dentistry, University of Alberta, Edmonton, Alberta, Canada

${ }^{3}$ Department of Internal Medicine, Jalalabad Ragib Rabeya Medical College and Hospital, Sylhet, Bangladesh

${ }^{4}$ Department of Cardiology, Sylhet MAG Osmani Medical College Hospital, Sylhet, Bangladesh
Correspondences:

Md Faruque Miah

Email: faruque-btc@sust.edu Sanjana Fatema Chowdhury

Email: sanjanafatema18@gmail.com

Address: Department of Genetic Engineering and Biotechnology, School of Life Sciences, Shahjalal University of Science and Technology, Sylhet 3114, Bangladesh

Received: 05.11.2021,

Accepted: 30.12 .2021

https://doi.org/10.29333/jcei/11706

Objectives: Sickle cell anemia is the most common genetic disorder that affects hemoglobin. People with this disorder have atypical hemoglobin molecules called hemoglobin $\mathrm{S}$, which can distort red blood cells into a sickle, or crescent shape. Sickle cell disease is an increasing global health problem. Estimates suggest that every year approximately 300,000 infants are born with sickle cell anemia, which is defined as an autosomal recessive disorder. The objective of this study is to show that the newborn screening of sickle cell anemia is possible through the procedure by utilizing the cord blood.

Materials and Methods: A total number of 30 samples were collected from individual mother and cord blood. DNA was extracted from 13 mothers and 13 fetal cord blood samples and used these DNA to detect sickle cell anemia using wild type and mutant type primer.

Results: $\beta$ hemoglobin gene was amplified by wild type and mutant type primer using PCR and revealed $517 \mathrm{bp}$ and $267 \mathrm{bp}$ length DNA fragments, respectively. In this study, it was observed that only one homozygous ( $\mathrm{Hb} \mathrm{S} / \mathrm{S}$ ) mother and newborn found. Most of the mothers and newborns were carrier of sickle cell anemia which means they were heterozygous $(\mathrm{Hb} A / \mathrm{S})$. Two pairs were found where mother was carrier, but newborns were healthy $(\mathrm{Hb}$ A/A).

Conclusions: With this study, it can come to the point that the newborn screening of sickle cell anemia is possible through the procedure by utilizing the cord blood that is wasted every time during delivery. By maternal screening in this way, the probability of disease transmission can also be checked earlier. For Bangladesh, this approach can be an effective tool for screening sickle cell anemia.

Keywords: $\beta$ hemoglobin, cord blood, inheritance, newborn screening, sickle cell anemia

\section{INTRODUCTION}

Hemoglobinopathy is one of the global crucial health dilemmas whereas around $7 \%$ of the inhabitants are carrier of hemoglobin disorders [1]. The abnormal molecular structure of hemoglobin generates the hemoglobinopathies where sickle cell anemia is one of the main hemoglobinopathy in many regions of the world including the Southeast Asia as well as Bangladesh.

Hemoglobin disorders originally affected $75 \%$ of births, potentially affecting $60 \%$ of the countries. But now, it is more common and prevalent in almost $89 \%$ of births and thus need much attention for treatment and prevention. A significant variant is carried by no less than $5.2 \%$ of the world population containing more than $7 \%$ pregnant women. Hemoglobin $S$ is responsible for $40 \%$ of carriers but causes over $85 \%$ of sickle-cell disorders because of localized very high carrier prevalence [2].

2.7 conceptions among 1000 are affected with a hemoglobin disorder causing around $1.1 \%$ of parents worldwide at risk. Still, preventive measures can make only a small. impression. In high-income countries most 
affected children survive with a chronic disorder, while in low-income countries most die before the age of 5 years. Hemoglobinopathies accounts for almost $3.4 \%$ of mortality in children who are less than 5 years globally [3].

A person with a mutation in both copies of the gene gets the sickle cell anaemia. Until about 6 weeks of age after birth hemoglobin $\mathrm{F}$ dominates, then, haemoglobin $\mathrm{A}$ takes over throughout life. Both $\beta$-globin subunits in haemoglobin $\mathrm{A}$ are replaced with haemoglobin $S$ in people diagnosed with sickle cell anaemia [4]. On the other hand, a single abnormal copy with a normal copy of the hemoglobin gene causes sickle cell trait. Such people are also referred to as carriers. Usually, there is no health problem in sickle cell trait unless exposed to extreme conditions like dehydration and altitude.

Sickle-cell disease is one of the most common monogenic disorders associated with phases of acute illness and progressive organ damage [5]. Hemoglobin S (HbS) is caused by a mutation in the 17 th nucleotide of $\beta$-globin gene where thymine is changed to adenine and consequently, the sixth amino acid becomes valine instead of glutamic acid. A hydrophobic motif is produced in the deoxygenated $\mathrm{HbS}$ tetramer due to this mutation that results in binding between $\beta 1$ and $\beta 2$ chains of two haemoglobin molecules. A polymer nucleus is produced from this crystallisation, which grows and fills the erythrocyte. Thus, the architecture and flexibility are disrupted, and cellular dehydration and oxidative cellular stress are promoted [6].

In Bangladesh, anemia has found to have greater significance in public health problem. It has been estimated in recent years that anemia is affecting the life of 27 million children and women [7]. It affects the quality of life, particularly among the poor by hampering health, physical and mental productivity. But the severe conditions are found in children who are carry sickle cell anemia, showing much difficulty in different stages of life span. For survival and development of present and future generations, it has become more important to give emphasis on the prevention and control of anemia in Bangladesh. Along with iron deficiency anemia, sickle cell anemia also recognized in Bangladesh, but the information regarding sickle cell anemia was found very tiny. Detection of sickle cell anemia is much more difficult than iron deficiency anemia as this disease is caused by specific gene. In addition, the recognition of the inheritance pattern of this gene is also problematic and cost effective. Therefore, in this research, easiest and simple costeffective PCR based molecular detection of beta hemoglobin gene and transmission pattern of sickle cell anemia in Bangladesh was considered.

\section{MATERIALS AND METHODS}

\section{Ethics Statement}

The methodology and protocol used for this study were reviewed and endorsed by the Graduate Research Ethics Committee (headed by the Dean of the School of Life Sciences), Shahjalal University of Science and Technology
(SUST), Sylhet, Bangladesh. The ethical approval number is IEC-101(1)/003. The procedure followed Helsinki Declaration of 1975 , as revised in 2000. Since the main participants of this study were pregnant women in the labor unit of the hospital, they were verbally told about the research and enrolled after their guardians provided written consent. A unique identification number was given to each of the samples collected to reduce the identification bias.

\section{Patient Enrolment and Sample Collection}

This study was conducted in the department of Genetic Engineering and Biotechnology at SUST and samples were collected from the Department of Gynecology and Obstetrics at Sylhet MAG Osmani Medical College and Hospital, Sylhet, Bangladesh. Approximately $2 \mathrm{ml}$ of peripheral blood was drawn into a $\mathrm{K}_{3}$-EDTA vial (JMI, Bangladesh) from the mothers. Cord blood was collected from the fatal end of the umbilical cord using gravitational fall down technique. Subject information's were also collected in a newly developed questionnaire form.

\section{DNA Extraction}

The traditional phenol-chloroform method was used for the isolation of DNA from the blood samples. Phenol chloroform extraction is an easy way to remove proteins from samples. Nucleic acid remains in the aqueous phase. On the other hand, protein separates in the organic phase or lies at the interface. A good quality DNA was observed in all the experimental sample with $0.1 \%$ agarose.

\section{PCR Amplification}

Wild type and mutant sets of primers were selected for detection of beta hemoglobin gene and the mode of sickle cell anemia [8]. The PCR reaction was performed for differentiating between the healthy individuals and the patients of sickle cell anaemia. Total $15 \mu$ l of PCR mixture was used in each sample to perform the PCR experiment. PCR reaction started with pre-heating at $95^{\circ} \mathrm{C}$ for 2 minutes, then denaturation at $95^{\circ} \mathrm{C}$ for 30 seconds. Annealing was done at $60^{\circ} \mathrm{C}$ for 30 seconds and 35 seconds were given for elongation or extension at $75^{\circ} \mathrm{C}$. A final step of 10 minutes at $72^{\circ} \mathrm{C}$ was added to allow complete extension of the amplified fragments. A total of 30 cycles were run for the complete PCR. The PCR products were then electrophoresed and analyzed on a $1.4 \%$ agarose gel.

\section{RESULTS}

After checking the DNA quality, samples were analyzed for detection of beta hemoglobin sickle cell anemia. Two specific primers were used. One for amplifying 517 bp fragment of normal beta globin gene. Second pair of primer for amplifying the $267 \mathrm{bp}$ fragment for mutant DNA for sickle cell disorder. In the outer lane $1 \mathrm{~kb}$ plus ladder range started from $250 \mathrm{~kb}$ length was used for the experiment.

PCR products were analyzed by agarose gel electrophoresis. 13 pairs of the sample were run for gel electrophoresis. Each pair consist of the mother and the fetal 


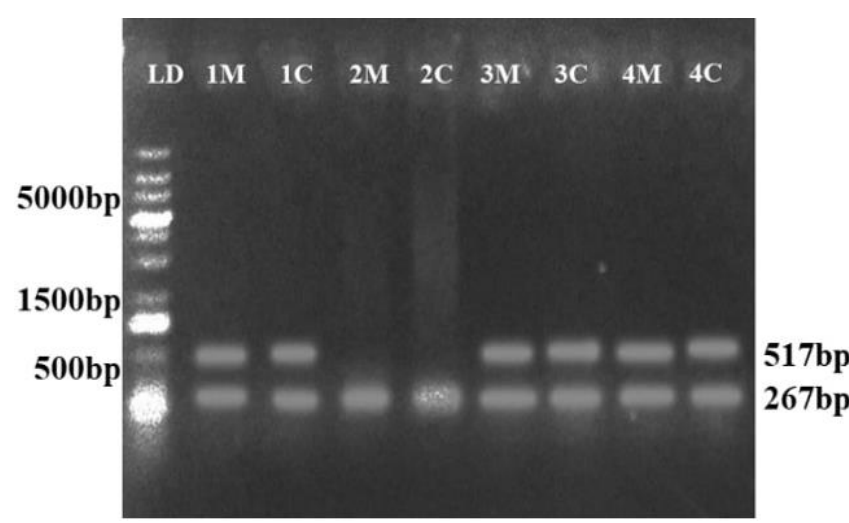

Figure 1. Representative gel images for the mother and cord blood samples (1-13)-1

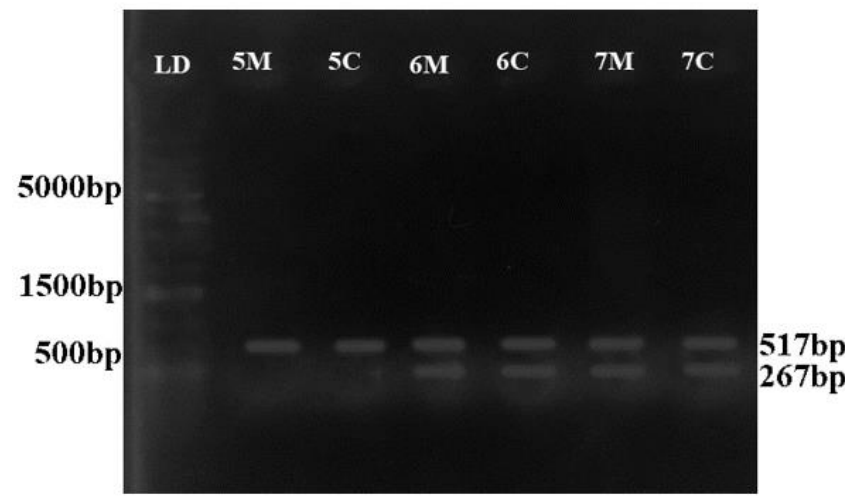

Figure 2. Representative gel images for the mother and cord blood samples (1-13)-2

Table 1. Correlation between seven pairs of mothers and newborn heterozygotes

\begin{tabular}{ccccccc}
\hline \multirow{2}{*}{$\begin{array}{c}\text { Sample } \\
\text { No }\end{array}$} & Age & $\begin{array}{c}\text { Mlood } \\
\text { Group }\end{array}$ & $\begin{array}{c}\mathrm{Hb} \\
\text { Level }\end{array}$ & Anemia & $\begin{array}{c}\text { New- } \\
\text { Disease } \\
\text { Condition's }\end{array}$ \\
$\begin{array}{ccccccc}\text { Born's } \\
\text { Disease } \\
\text { Condition }\end{array}$ \\
\hline $\mathbf{1}$ & 20 & $\mathrm{AB}+$ & 5.8 & Present & $\mathrm{Hb} \mathrm{A} / \mathrm{S}$ & $\mathrm{Hb} \mathrm{A} / \mathrm{S}$ \\
\hline $\mathbf{3}$ & 25 & $\mathrm{O}+$ & 6.6 & Present & $\mathrm{Hb} \mathrm{A} / \mathrm{S}$ & $\mathrm{Hb} \mathrm{A} / \mathrm{S}$ \\
\hline $\mathbf{4}$ & 30 & $\mathrm{~B}+$ & 7.0 & Present & $\mathrm{Hb} \mathrm{A} / \mathrm{S}$ & $\mathrm{Hb} \mathrm{A} / \mathrm{S}$ \\
\hline $\mathbf{6}$ & 35 & $\mathrm{~B}+$ & 6.7 & Present & $\mathrm{Hb} \mathrm{A} / \mathrm{S}$ & $\mathrm{Hb} \mathrm{A} / \mathrm{S}$ \\
\hline $\mathbf{7}$ & 19 & $\mathrm{~B}+$ & 6.6 & Present & $\mathrm{Hb} \mathrm{A} / \mathrm{S}$ & $\mathrm{Hb} \mathrm{A} / \mathrm{S}$ \\
\hline $\mathbf{9}$ & 20 & $\mathrm{~B}-$ & 6.0 & Present & $\mathrm{Hb} \mathrm{A} / \mathrm{S}$ & $\mathrm{Hb} \mathrm{A} / \mathrm{S}$ \\
\hline $\mathbf{1 2}$ & 21 & $\mathrm{~A}+$ & 6.4 & Present & $\mathrm{Hb} \mathrm{A} / \mathrm{S}$ & $\mathrm{Hb} \mathrm{A} / \mathrm{S}$ \\
\hline
\end{tabular}

cord blood. Three modes of inheritance were found from the PCR product analysis.

One type of inheritance is the carrier of the sickle cell anemia for both mother and the fetal cord blood. This is the most commonly found inheritance where the bands were observed at the length of both $517 \mathrm{bp}$ and $217 \mathrm{bp}$. Seven pairs (Table 1) of sample like sample $1 \mathrm{M}, 1 \mathrm{C}, 3 \mathrm{M}, 3 \mathrm{C}, 4 \mathrm{M}, 4 \mathrm{C}$ (Figure 1), 6M, 6C, 7M, 7C (Figure 2), 9M, 9C (Figure 3), $12 \mathrm{M}$, and 12C (Figure 4) showed both bands which means that the mother and the new born both are the carrier of sickle cell anemia, where $M$ refers to mother samples, $C$

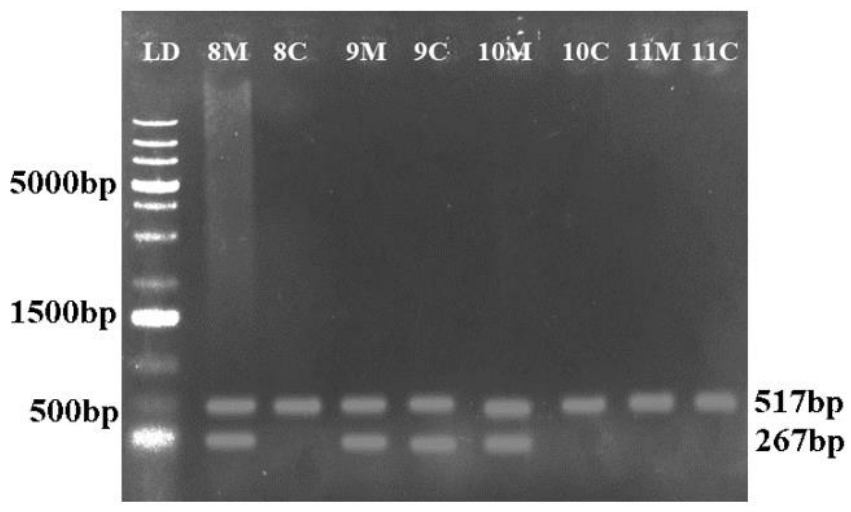

Figure 1. Representative gel images for the mother and cord blood samples (1-13)-3

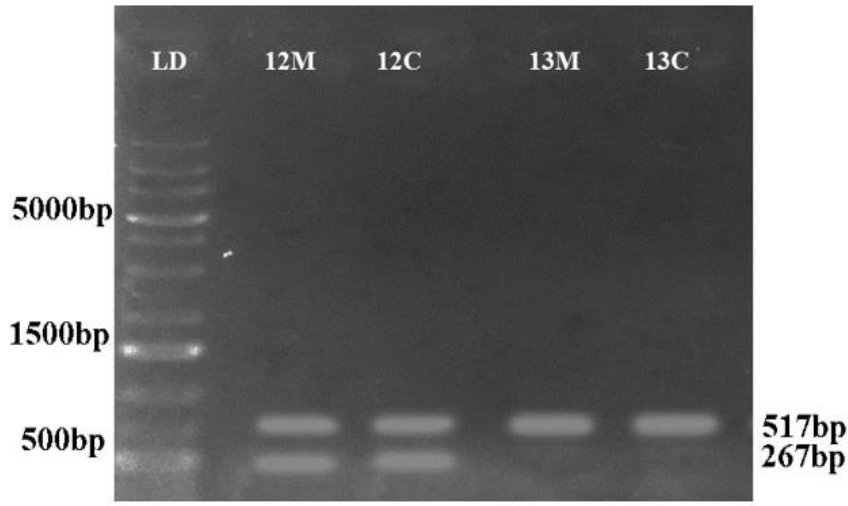

Figure 4. Representative gel images for the mother and cord blood samples (1-13)-4

Table 2. Correlation between three pairs of normal mothers and new-born

\begin{tabular}{|c|c|c|c|c|c|c|}
\hline \multirow[b]{2}{*}{$\begin{array}{c}\text { Sample } \\
\text { No }\end{array}$} & \multicolumn{5}{|c|}{ Mother's Medical History } & \multirow{2}{*}{$\begin{array}{c}\text { New- } \\
\text { Born's } \\
\text { Disease } \\
\text { Condition }\end{array}$} \\
\hline & Age & $\begin{array}{l}\text { Blood } \\
\text { Group }\end{array}$ & $\begin{array}{c}\mathrm{Hb} \\
\text { Level }\end{array}$ & Anemia & $\begin{array}{l}\text { Disease } \\
\text { Condition }\end{array}$ & \\
\hline 5 & 22 & $A B+$ & 11.3 & Absent & $\mathrm{Hb} \mathrm{A} / \mathrm{A}$ & $\mathrm{Hb} \mathrm{A} / \mathrm{A}$ \\
\hline 11 & 23 & $A B+$ & 12.4 & Absent & $\mathrm{Hb} \mathrm{A} / \mathrm{A}$ & $\mathrm{Hb} \mathrm{A} / \mathrm{A}$ \\
\hline 13 & 25 & $\mathrm{~B}+$ & 12.1 & Absent & $\mathrm{Hb} \mathrm{A} / \mathrm{A}$ & $\mathrm{Hb} \mathrm{A} / \mathrm{A}$ \\
\hline
\end{tabular}

refers to cord blood samples, and LD refers to $1 \mathrm{~kb}$ plus DNA ladder.

Second mostly found inheritance is the healthy individuals. The band was only found at the length of the $517 \mathrm{bp}$. That means the 3 pairs (Table 2) of samples like 5M, 5C (Figure 2), 11M, 11C (Figure 3), 13M, and 13C (Figure 4) are healthy individuals.

Another type of inheritance found in 2 pairs (Table 3 ) of samples like 8M, 8C, 10M, 10C (Figure 3) where the mothers were carrier of sickle cell anemia, but the newborns were healthy individual because the mother blood samples showed two bands, but the newborns showed band only at the length of $517 \mathrm{bp}$. 
Table 3. Correlation between two pairs of heterozygous mothers and healthy new-born

\begin{tabular}{|c|c|c|c|c|c|c|}
\hline \multirow[b]{2}{*}{$\begin{array}{c}\text { Sample } \\
\text { No }\end{array}$} & \multicolumn{5}{|c|}{ Mother's Medical History } & \multirow{2}{*}{$\begin{array}{c}\text { New- } \\
\text { Born's } \\
\text { Disease } \\
\text { Condition }\end{array}$} \\
\hline & Age & $\begin{array}{l}\text { Blood } \\
\text { Group }\end{array}$ & $\begin{array}{c}\text { Hb } \\
\text { Level }\end{array}$ & Ane & $\begin{array}{l}\text { Disease } \\
\text { Condition }\end{array}$ & \\
\hline 8 & 25 & $A+$ & 7.2 & Present & $\mathrm{Hb} \mathrm{A} / \mathrm{S}$ & $\mathrm{Hb} \mathrm{A} / \mathrm{A}$ \\
\hline 10 & 20 & $A B+$ & 7.2 & Present & $\mathrm{Hb} \mathrm{A} / \mathrm{S}$ & $\mathrm{Hb} \mathrm{A} / \mathrm{A}$ \\
\hline
\end{tabular}

Only one pair (Table 4) of samples 2M, 2C showed the homozygous inheritance which means the band found only at the length of $217 \mathrm{bp}$ (Figure 1) of both mother and fetal cord blood.

From the PCR product analysis, it has also been observed that the subject information was totally linked to it. The subject information expresses that the mothers those are anemic also showed homozygosity and heterozygosity of sickle cell anemia.

\section{DISCUSSION}

Several experiments were in practice to detect hemoglobinopathies using venous blood samples $[9,10]$. Generally, peripheral blood is used for the molecular diagnosis of sickle cell anemia. In some cases of prenatal diagnosis amniotic fluid is in practice worldwide [11]. Another common practice is newborn screening for reducing disease-related mortality due to sickle cell anemia [12] and it is mainly done using blood from heel prick [13]. In case of developing country like Bangladesh, most of the people are not concerned about newborn screening after birth but newborn screening has also been established in recent years in these developing countries [14]. Though newborn screening has been practiced now a day, the parents are unwilling to give blood from heel prick or vein of the newborn. Considering these circumstances, this study was done using umbilical cord blood which is considered as wastage after delivery.

DNA extraction method mostly used now a days are with DNA extraction kit [15]. But in this experiment, all the buffers and the solutions were prepared in the lab and DNA extraction was done manually following the phenol chloroform method. This method may be time consuming but more cost effective. And DNA can be extracted more accurately than extracting the DNA using DNA extraction kit.

Various methods and new technologies like new generation sequencing, multiple ligation dependent probe amplification [16], cation exchange high performance chromatography, and tandem mass spectrometry $[17,18]$ are in recent practice for diagnosis of hemoglobinopathy. However, countries with less advanced techniques, electrophoresis and PCR studies are still used for the newborn screening [19]. Therefore, a simple method was established for this experiment using the PCR technique and
Table 4. Correlation between one pair of homozygous mother and new-born

\begin{tabular}{ccccccc}
\hline \multirow{2}{*}{$\begin{array}{c}\text { Sample } \\
\text { No }\end{array}$} & \multicolumn{4}{c}{ Mother's Medical History } & $\begin{array}{c}\text { New- } \\
\text { Born's }\end{array}$ \\
\cline { 2 - 6 } & Age & $\begin{array}{c}\text { Blood } \\
\text { Group }\end{array}$ & $\begin{array}{c}\mathrm{Hb} \\
\text { Level }\end{array}$ & Anemia & $\begin{array}{c}\text { Disease } \\
\text { Condition }\end{array}$ & $\begin{array}{c}\text { Disease } \\
\text { Condition }\end{array}$ \\
\hline $\mathbf{2}$ & 19 & $\mathrm{~B}+$ & 6.3 & Present & $\mathrm{Hb} \mathrm{S} / \mathrm{S}$ & $\mathrm{HbS} / \mathrm{S}$ \\
\hline
\end{tabular}

gel electrophoresis analysis so that newborn screening might not consider impossible or expensive.

The final target of the study was to detect beta hemoglobin gene. The screening of the patients of sickle cell anemia can be done based on this gene detection. For the identification of beta hemoglobin gene two types of primer have been used. One is the wild type primer and another one is the mutant type primer which means they amplify $517 \mathrm{bp}$ and $267 \mathrm{bp}$, respectively. Single tube allele specific PCR is used in a low-cost technique for molecular screening of sickle cell anemia in Nigeria with similar primers [20].

From the study, most of the individuals are found to be carrier of sickle cell anemia and some are healthy person. Only one homozygous mother and newborn were found. And one mother was found who herself is a carrier of sickle cell anemia, but the newborn is healthy individual. The whole study indicates the inheritance patter of the sickle cell anemia.

The overall result of the study showed that the PCR analysis of cord blood sample may establish an effective method to detect the normal condition of the newborn as well as the diseased condition. Thus, the cord blood can be utilized. If the mother or both the parents are screened through the process, then the probability checking of passing the disease to the child can be done and further treatment can be done according to that. That is why screening of parents with the newborn is also an important issue for the management of sickle cell anemia

Author contributions: FL and SA: did the experimental studies. SC: prepared and edited the manuscript. SC and SA: analysed the data. SA and MM: conceptualized and designed the project. RR, MRM, and MF: worked in data acquisition and literature search. All authors reviewed the manuscript. All authors have sufficiently contributed to the study, and agreed with the results and conclusions.

Funding: This study was partially supported by the annual research allocation of the Department of Genetic Engineering and Biotechnology, Shahjalal University of Science and Technology, Bangladesh. SA is supported by the Alberta Innovates Graduate Student Scholarship (AIGSS) and the Maternal and Child Health (MatCH) Scholarship programs. MM receives grant support from the (1) SUST Research Center, (2) Bangladesh Bureau of Educational Information and Statistics (BANBEIS), (3) the Ministry of Education, and the (4) Ministry of Science and Technology, Government of Bangladesh.

Acknowledgements: The authors acknowledge the co-operation of the Department of Gynaecology and Obstetrics, Sylhet MAG Osmani Medical College, Sylhet, Bangladesh during the study.

Declaration of interest: No conflict of interest is declared by authors. 


\section{REFERENCES}

1. Kohne E. Hemoglobinopathies: Clinical manifestations, diagnosis, and treatment. Dtsch Arztebl Int 2011;108(3132):532-40. doi: 10.3238/arztebl.2011.0532.

2. Global epidemiology of haemoglobin disorders and derived service indicators. WHO. Available at: https:// www.who.int/bulletin/volumes/86/6/06-036673/en/ (Accessed: 14 May 2021).

3. Modell B, Darlison M. Global epidemiology of haemoglobin disorders and derived service indicators. Bull World Health Organ 2008;86(6):480-7. doi: 10.2471/BLT.06.036673.

4. Costa FF, Conran N. Sickle cell anemia: From basic science to clinical practice, $1^{\text {st }}$ edn. Cham: Springer, 2016. doi: 10.1007/978-3-319-06713-1.

5. Rees DC, Williams TN, Gladwin MT. Sickle-cell disease. Lancet 2010;376(9757):2018-31. doi: 10.1016/S01406736(10)61029-X.

6. Brittenham GM, Schechter AN, Noguchi CT. Hemoglobin S polymerization: Primary determinant of the hemolytic and clinical severity of the sickling syndromes. Blood 1985;65(1):183-9. doi: 10.1182/ blood.V65.1.183.183.

7. Rahman SA, Rahaman MS, Shipa SA, et al. Detection of $\beta$-hemoglobin gene and sickle cell disorder from umbilical cord bood. J Biosci Med 2017;5(10):51-63. doi: 10.4236/jbm.2017.510006.

8. Waterfall CM, Cobb BD. Single tube genotyping of sickle cell anemia using PCRbased SNP analysis. Nucleic Acids Res 2011;29(23):e119-e119. doi: 10.1093/nar/29.23.e119.

9. Gupta SP, Hanash SM. Separation of hemoglobin types by cation-exchange high-performance liquid chromatography. Anal Biochem 1983;134(1):117-21. doi: 10.1016/0003-2697(83)90271-3.

10. Abdelazim MF, Ali EW, Abdelgader EA. Comparison between PCR-based single tube genotyping of sickle cell disease and alkaline haemoglobin electrophoresis. J Adv Med Med Res 2015;10(9):1-6. doi: 10.9734/BJMMR/ 2015/18759.
11. Begum K, Mannan MA, Sanyal M, Hosen MI, Chakraborty S. Molecular diagnostic approach prevails superior over conventional gel-electrophoresis method in detecting sickle cell anemia. J Mol Biomark Diagn 2018;9(382):2. doi: 10.4172/2155-9929.1000382.

12. Alvarez OA, Hustace T, Voltaire M, et al. Newborn screening for sickle cell disease using point-of-care testing in low-income setting. Pediatrics 2019;144(4):e20184105. doi: 10.1542/peds.2018-4105.

13. Therrell BL, David-Padilla C. Screening of newborns for congenital hypothyroidism: Guidance for developing programmes. Vienna: IAEA, 2005:122.

14. Moslem F, Yasmeen S, Hasan M, et al. Newborn screening: Experience of Bangladesh. Southeast Asian J Trop Med 2004;34:71-2.

15. Lin Z, Suzow JG, Fontaine JM, Naylor EW. A simple automated DNA extraction method for dried blood specimens collected on filter paper. JALA: J LabAutom 2005;10(5):310-4. doi: 10.1016/j.jala.2005.07.004.

16. Traeger-Synodinos J, Harteveld CL. Advances in technologies for screening and diagnosis of hemoglobinopathies. Biomark Med 2014;8(1):119-31. doi: 10.2217/bmm.13.103.

17. Moat SJ, Rees D, George RS, et al. Newborn screening for sickle cell disorders using tandem mass spectrometry: Three years' experience of using a protocol to detect only the disease states. Ann Clin Biochem 2017;54(5):601-11. doi: 10.1177/0004563217713788.

18. Lobitz S, Klein J, Brose A, Blankenstein O, Frömmel C. Newborn screening by tandem mass spectrometry confirms the high prevalence of sickle cell disease among German newborns. Ann Hematol 2019;98(1):47-53. doi: 10.1007/s00277-018-3477-4.

19. Riou J, Godart C, Hurtrel D, et al. Cation-exchange HPLC evaluated for presumptive identification of hemoglobin variants. Clin Chem 1997;43(1):34-9. doi: 10.1093/clinchem/43.1.34.

20. Toye ET, van Marle G, Hutchins W, Abgabiaje O, Okpuzor JO. Single tube allele specific PCR: A low cost technique for molecular screening of sickle cell anaemia in Nigeria. Afr Health Sci 2018;18(4):995-1002. doi: 10.4314/ahs.v18i4.20. 